\title{
ARTICLES
}

\section{HIGHER EDUCATION \\ IN CANADA AND THE UNITED STATES: EXPLORING THE ROOTS OF DIFFERENCE ${ }^{1}$}

\author{
Paul Axelrod
}

As an historian of higher education, I have long been aware of the failure of scholars to address adequately a fundamental question about university development in North America: how can important differences between Canadian and American higher education be explained? While brief commentaries on the contrasting nature of university life in the two nations have periodically appeared, higher education has rarely been the subject of systematic comparative analysis. ${ }^{2}$ Focusing on the issues of university growth and studem participation rates, this article attempts such an investigation. Why, from the mid-nineteenth century until the recent past, did a significantly larger proportion of Americans than Canadians, especially women, attend post-secondary educational institutions? The following discussion examines the interplay of two forces that have been largely unexamined with respect to their relevance to this matter: religion and economics. Evangelical Christianity combined with the dynamics of a burgeoning capialist economy to generate a greater degree of post-secondary educational development in the United States than in Canada.

1. I would like to thank the following individuals for their helpful comments on earlier versions of this paper: John G. Reid, H.V. Nelles, Alison Prentice, and William Westall.

2. Brief commentaries include Leonard Stem, "Degrees of Education," Globe and Mail, 3 Aug. 1993; Susan Catto, "An Elucated Look at U.S. Schools," Globe and Mail, 12 Aug. 1993. More extensive treatments include Henry Srebnik, "Fooball, Frats, and Fun vs Commuters, Cold, and Carping: The Social and Psychological Context of Higher Education in Canada and the United States," in Canada and the United States: Differences that Count, ed. David Thomas (Toronto: Broadview Press, 1993), 380-407; Michacl L. Skolnik and Glen A. Jones, "A Comparative Analysis of Alrangements for State Co-ordination of Higher Education in Canada and the United States,"Joumal of Higher Education 63,2 (Mar./Apr. 1992): 121-42. 
The article begins with a discussion of existing historiographical approaches that bear on this question. It then details, in statistical terms, post-secondary educational participation rates in Canada and the United States, grappling in the process with the ambiguities involved in the use of such statistics. Next, it examines the comparative impact of denominationalism on the development of higher education in Canada and the United States in the nineteenth century. Finally, it explores the effect of economic and labour market trends on the participation of the population in higher education.

Some scholars contend that proportionately more Americans than Canadians attend universities and colleges because the United States is, and has been, a more democratic and egalitarian society than Canada. ${ }^{3}$ At best this thesis provides only partial insight into the differences between Canadian and American political culture; indeed, critics have challenged the argument fundamentally. Its simplistic historical sweep, its insensitivity to regional variations in attitude within both Canada and the United States, and its failure to account adequately for some distinctly inegalitarian aspects of American society have been called into question. For example, the claim that Canada is less egalitarian than the United States is difficult to reconcile with the democratizing impact of state-funded social services in Canada, including universal health care. ${ }^{4}$ With respect to higher education, while it is indisputable that proportionately more Americans than Canadians have received advanced education, Blacks, Jews, and women-in both countries-were subjected to myriad forms of discrimination well into the twentieth century. ${ }^{5}$ Furthermore, as Fritz Ringer notes, the degree of intergen-

3. Seymour Martin Lipset, Continental Divide: The Values and Institutions of the United States and Canada (New York: Routiedge, 1990), 8, 11, 24-26, 158-61.

4. Critiques of Lipset include Doug Baer, Edward Grabb, and William A. Johnston, "The Values of Canadians and Americans: A Reassessment," Social Forces 68, 3 (Mar. 1990): 693-713, and D. Baer et al., "National Character, Regional Culture, and the Values of Canadians and Americans," Canadian Review of Sociology and Anthropology 30, 1 (Feb. 1993): 13-30.

5. On discriminatory practices in higher education, for Canada, see Irving Abella, A Coat of Many Colours: Two Centuries of Jewish Life in Canada (Toronto: Lester and Orpen Denys, 1990), 219; Paul Axelrod, Making a Middle Class: Student Life in English Canada during the Thirties (Montreal: McGill-Queen's University Press, 1990), 32-34, 107, 118-21. On the United States, see Harold S. Wechsler, The Qualified Student: A History of Selective College Admission in America (New York: John Wiley and Sons, 1977); Marcia Graham Synnott, The Half-Opened Door: 
erational mobility from blue-collar to white-collar occupations has been no greater in the United States than in other advanced industrial societies. Class divisions and social inequality have been largely unaltered by the high participation rates of Americans in post-secondary education. ${ }^{6}$

Indeed, in some ways, American higher education has featured more, not less, elitism than that in Canada. The rigid institutional ranking of American universities, and the pervasiveness of a class-conscious fraternity life among their students, characterize the American, not the Canadian, university experience. While there may well have been a greater "populist" dimension to the development of education in the United States than in Canada, something beyond the elitist/egalitarian paradigm is required to explain patterns of university development and attendance in the two countries.

Is it possible that as a more advanced industrial capitalist society, the United States developed colleges and universities more rapidly than Canada? This article argues that there is some truth to this contention, particularly with respect to the late nineteenth and early twentieth centuries. But as other historians have noted, the precise link between education and economic development in the eighteenth and early nineteenth centuries is difficult to establish. During EngIand's extraordinary economic expansion in the early nineteenth century, university enrolments declined, and England also lagged behind less wealthy countries in the development of primary and secondary education. ${ }^{8}$ Andy Green argues that "new educational developments during the nineteenth century did not on the whole play a major role in economic development, nor is it clear that educational change was prompted in any way by the economic skill requirements thrown up by industrialization." If economic conditions alone cannot explain the early history of higher education in Canada and the United States, and if the elitist/egali-

Discrimination and Admissions at Harvard, Yale, and Princeton, 1900-1970 (Westport, Comn.: Greenwood Press, 1979); Gil Kujovich, "Equal Opportunities in Higher Education and the Black Public College: The Era of Separate But Equal," in The Struggle for Equal Education, Part 2, ed. Paul Finkelman (New York: Garland Publishing Inc, 1992), originally published in Minnesota Law Review 72, 29 (1987): 29-172.

6. Fritz K. Ringer, Education and Society in Modern Europe (Bloomington: Indiana Universily Press, 1979), 256-59. See also, Christopher Jencks and David Reisman, The Academic Revolution (New York: Doubleday and Co., 1968), chap. 3.

7. For a discussion of college "ranking" in the U.S., see Richard M. Freeland, Academia's Golden Age: Universities in Massachusetts, 1945-1970 (New York: Oxford University Press, 1992), 360-66. On fraternities, see Srebnik, "Football, Frats"; Paula Fass, The Damned and the Beautiful: American Youth in the 1920s (New York: Oxford, 1977), 142-57; and Axelrod, Making a Middle Class, 105-8.

8. Ringer, Education and Society in Modern Europe, 2.

9. Andy Green, Education and State Formation: The Rise of Education Systems in England, France and the U.S.A. (New York: St. Martin's Press, 1990), 40. 
tarian model inadequately addresses the comparative educational question, then other interpretive routes must be followed.

We are aided in our search by a lively historiographical debate about the nature of American higher education in the nineteenth century. Until recently, college life in the ante-bellum era was perceived, in Richard Hofstadter's words, as a "Great Retrogression"- -an era of slow "Death." 10 Wildly overbuilı and mostly unable to sustain themselves as viable citadels of higher learning, American colleges, according to this interpretation, were riven by sectarian strife, steeped in an outdated classical curriculum, and subjected to frequent student revolts. They also catered to a privileged clientele. Aftluent families sent sons with too much time on their hands to college in the hope of improving their disposition and social usefuness. Too often, the parents were disappointed paryly because the colleges, also, were aimless. ${ }^{\text {II }}$

In this historical rendition, not until the great transformation of the late nineteenth century, when the college curriculum was liberalized and reformed, when research and graduate training were embraced and sustained, when enrolments expanded significantly with the aid of the Morrill Act of 1862 , and when secular values seeped into mainstream academic culture, did American higher education come of age and enter the modem world. ${ }^{12}$ In recent years, this "whiggish" view has been challenged by historians who have painted a more positive picture of the "old time college." They claim that earlier historians overstated the rate of institutional failure, and that college enrolments actually increased significantly in the period before $1860 .{ }^{13}$ Furthemore, the ante-bellum denominationally led college was more intellectually vibrant, more in touch with community needs including those of women, more important to local economic life, and less stifled by religious dogmatism, than traditionally believed. Sudents

10. Cited in James Axtell, "The Death of the Liberal Arts College," in ASHE Reader on the History of Higher Education, ed. Lester F. Goodchild and Hayold S. Wescher (Needham Heights, Mass.: Ginn Press, 1989), 110.

11. See Oscar Handlin, The Americun University as an Instrument of Republican Cullure (New York: Humanities Press Inc., 1970), 9; Joseph Kell, Rites of Passuge: Adolescence in America, 1790 to the Present (New York: Basic Books, 1977), $51-59$.

12. Axtell, "The Death of the Liberal Arts College," 110. While generaly sharing this perspective, Latuence Veysey's The Emergence of the American University (Chicago: University of Chicago Press, 1965) is a suble and textured treatment of the period. Frederick Rudolph's The American Collegeand University: A History (New York: Alfred A. Knopf, 1962) also falls within this tradition, though he treats the "sectarian" era more positively than other historians, and he usefully explores the myth of the "private universily" in the U.S. (chaps. 3, 4, 9).

13. The most claborate statement on this question is Colin Burke, American Collegiate Populations: A Test of the Traditional View (New York and London: New York University Press, 1982). 
too were more serious, and more modes in their social origins than earlier historical accounts contend. In short, contrary to popalar myth, American higher education thrived, even if it did not always prosper, in the period before the rise of Charles Elliot and Johns Hopkins. ${ }^{14}$

It is probable, as Carol Gruber suggests, that the "revisionists" have implicilly understated the degree of change experienced by American colleges and universities in the late nineteenth century. The professionalization of academic life, the growing specialization of the curriculum, the deep impact of scientific thought and method, the effect of industrial change on higher education, and the enormous overall increase in enrolments after 1870, altered, as Laturence Veysey contends, both the substance and shape of higher education. ${ }^{5}$ However, the revisionists are correct to insist, as ate historians of religion and gender, that college life in the ante-bellum era should be taken seriously, and recent scholarship ably documents the dynamism and complexity of the period in a way that is pertinent to the cental concern of this article.

In Canada, historiographical debate on the nature of nineteenth-century higher education is far Iess extensive, in part as a reflection of the limited size of the system, which enrolled barely more than 1,500 students in seventeen institutions in 1871 . Historians generally agree that most of Canada's universities struggled 10 survive, and that, as in the United States, the ability of denominational colleges to redain their spiritual identities in an increasingly secular era was a cultural preoccupation, particularly in English-speaking Canada. ${ }^{16}$

14. See Robert T. Blackbum and Clifton F. Comad, "The New Revisionists and the History of Higher Education," in ASHE Reader on the History of Higher Education, 160-70; David Almendinger, Patpers and Scholars: The Transformation of Suden Life in Nineteenth Century New England (New York: St. Martin's Press, 1975); David Potts, "College Enthusiasms and Public Response, 1800-1860," Harvard Educational Review 47, 1 (Feb. 1977): 28-42; James Mclachlan, "The American College in the Ninefenth Century: Towatd a Reappraisal, Teachers College Record 80, 2 (Dec. 1978): 287-306; Jack C. Lane, "The Yale Report of 1828 and Liberal Education: A Neorepublican Manifesto," History of Edwcation Quarterly 27, 3 (Fall 1987): 326-38; Roger L. Geiger, "The Historical Matrix of American Higher Education," History of Higher Education Annual 12 (1992): 7-28, and "Responses," ibid., 29-34; George M. Marsden and Bradley J. Longfield, The Secularization of the Academy (New York: Oxford University Press, 1992).

15. Carol S. Gruber, "Backdrop," in Mars and Minerva: World War I and the Uses of Higher Leaming in America (1975), reprinted in ASHE Reader on the History of Higher Eduation, 181-96; Veysey, The Emergence of the American University, "Introduction." For an elaboration of this theme, see Burton J. Bledstein, The Culure of Professionalism: The Middle Class and the Development of Higher Education in America (New York: W.W. Norton and Co., 1976).

16. A.B. McKillop, A Disciplined Intelligence: Critical Inquiry and Canadian Thought in the Victorian Era (Montreal: McGilt-Queen's University Press, 1979); A.B. McKillop, Matters of Mind: The University in Ontario, 1791. 1951 (Toronto: 
In two important respects, however, the Canadian literature on nineteenthcentury higher education has evolved. First, historians are now far more cognizant of the educational experiences of women. Their involvement in pre-university denominationally run academies, their initial admission to universities, and their subsequent treament on campus have been the subject of increasing study. ${ }^{17}$ Second, historians have been engaged in an intense debate about the history of religious-particularly Protestan- - whought. Some scholars argue that religious authority in higher education, and society at large, was successfully challenged and finally undermined in the late nineteenth century by the material changes and intellectual currents arising from an emerging industrial capitalist society. ${ }^{18}$ Others contend that Protestant evangelicals were able to withstand these challenges, and, a least until the early twentieth century, they successfully reconciled modem science, educational teaching, and religious thought in their writing and teaching. ${ }^{19}$ A third group of historians explores the tensions, creative and otherwise, in nineteenth-century theological thinking. ${ }^{20}$

University of Torono Press, 1994); Patt Axchrod and John G. Reid, "Introduction," in Youh, University, and Canadian Society: Essays in the Social History of Higher Education (Montreal: McGill-Quen's Universily Press, 1989), xiv.

17. Examples include: John G. Reid, "The Education of Women at Mount Allison, 1854-1914," Acadiensis 12, 2 (Spring 1983): 3-33; Johanna Selles-Roney, "Manners and Morals?' or 'Men in Petticoats'?: Education at Alma College, 1871-1898," in Gender and Education in Ontario, ed. Ruby Healy and Alison Prentice (Toronto: Scholars Press, 1991), 247-67; Paula J.S. LaPierre, "The First Generation: The Experience of Women University Students in Central Canada" (Ph.D diss., University of Toron10, 1992); Judith Fingard, "College, Career and Community: Dalhousic Coeds, 1881-1921," in Youth, University, and Canadian Society: Essays in the Social History of Higher Education, ed. Paul Axelrod and Joln G. Reid (Montreal: McGill-Queen's University Press, 1989), 26-50; Lyme Marks and Chad Gaffield, "Women at Queen's University, 1895-1900: A Litte Sphere all Their Own?" Ontario History 77, 4 (Dec. 1986): 331-49.

18. McKillop, A Disciplined Intelligence; David Marshall, Secularizing the Faith: Canadian Protestan Clergy and the Crisis of Belief, 1850-1940 (Toronto: University of Toronto Press, 1992).

19. Michael Gauvreau, The Evangelical Century: College and Creed in English Canada from the Great Revival to the Great Depression (Montreal: McGill-Quecn's University Press, 1991); Marguerite Van Die, An Evangelical Mind: Nathanael Burwash and the Methodist Tradition in Canada, 1839-1918 (Montreal: McGill-Queen's University Press, 1989).

20. William Westall, Two Worlds: The Protestant Culture of Nineteenth-Century Ontario (Montjeal: McGill-Queen's University Press, 1989); John Webster Grant, A Profusion of Spires: Religion in Nineteenth-Century Ontario (Totonto: University of Toronto Press, 1988); George Rawlyk, ed., The Canadian Protestant Experience, 1760-1990 (Burlington, Ont.: Welch, 1991); G.A. Rawlyk, ed., Canadian Baptists and Christian Higher Education (Montreal: McGill-Queen's University 
Although these historians do not always examine directly the links between higher education and religion, the connection bears consideration in the context of the discussion that follows. Indeed, by reopening the question of the relationship between religion, education, and society in the nineteenth century, historians in both countries provide the basis for comparing anew university development in Canada and the United States. When considered in the light of accompanying economic changes, attention to religion informs our understanding of the comparative size and growth of higher education in the two countries.

Before exploring the problem directly, it is important to explain what is meant by "participation rates" in higher education, and how they can be measured. Usually, statisticians calculate for a given year the percentage of a nation's youth (generally aged 18-21 or 18-24) that is enrolled in what is defined as a post-secondary educational institution. This assumes that students are "young," a presumption that is undoubtedly true for the majority of North American students, but one that fails to account for a significant percentage of older students in the early nineteenth century, or for the growing participation of older "life-long adult Iearners" in the contemporary period. ${ }^{21}$ Recent calculations have in some cases attempted to isolate the younger attenders, but historically this was not done, and distortions might still exist in the participation-rate measurements. In order to avoid this dilemma, one might calculate the percentage of a country's total population enrolled in higher education in a specific year. Age discrepancies thus become irrelevant.

An additional challenge in analyzing the two countries' participation rates is, as we shall see, the problem of comparable data, particularly over an extended period of time. Are the same types of institutions considered to offer higher education in both countries? Are the institutional definitions within and between

Press, 1988).

21. David F. Allmendinger, Jr, notes that in the early nineteenth century, more than a third of students in New England graduated at 25 years of age or more: "New England Students and the Revolution in Higher Education, 1800-1900," in The Social History of American Education, ed. B. Edward McClellan and William I. Reese (Urbana and Chicago: University of llinois, 1988), 66. In 1990, students 25 years of age and older constituted 24 percent of all full-time enrolments in Canada: Norman Uhl and Ame Marie Mackinnon, "Students," in Higher Education in Canada, ed. A. Gregor and G. Jasmin (Ottawa: Ministry of Supply and Services, 1992), 48 . 
nations consistently sustained? The answer is frequently in the negative, and the data, consequently, are imperfect. The best one can hope to achieve is a reflection of patterns in the rate of participation which allows for reasonable, if approximate, comparative assessments.

On the following pages 1 present estimated participation rates in higher education for the population as a whole from 1870-71 to 1980-81. Comparable data on the age group 18-24 are not available until 1930-31. These initial figures are based on official statistics.

Table 1 reveals that, per capian, almost three times as many Americans as Cantadians were attending institutions of higher leaming in 1870, a gap that remained more or less constant 10 1930. Thus official statistics indicate that the rate of expansion in a period of major growth was similar in both countries. In terms of the age group 20-24, approximately four times as many Americans as Canadians were enrolled in higher educational institutions in 1930 (Table 2). It should be noted that while the rate of enrolment in the two countries maly have been similar over this period, the United States registered full-time more than one million students in 1930 compared to just over 30,000 in Canada. Not only did a significantly higher proportion of the population obtain at least some post-secondary schooling in the United States, but the system of higher education was considerably larger and more diverse than that in Canada.

In the post-war period, particulaly after 1960, both countries experienced a significant increase, proportionately and absolutely, in higher educational enrolments, though the participation-rate gap between the wo nations closed somewhat. As Table 3 shows, the university participation rate of Canadians aged 18-24 doubled between 1957 and 1967, whereas in the United States, it increased by one-half. By the mid-1980s, if one were to count all post-secondary enrolments (including community colleges in Canada and junior colleges in the U.S.), Canada and the United States had almost achieved equity, and ranked far above all other industrial countries in terms of student participation rates in post-secondary education (Table 4).

Thus, to understand the origins of the original participation-rate gap, one must examine developments in the nineteenth century, particularly before 1870 . Official statistics, as noted, would indicate that the three-fold gap in participation rates did not change over the next half-century, and in the decades that followed World War II, the gap increasingly closed. 
Table 1: Participation Rates in Higher Education

\begin{tabular}{|c|c|c|c|}
\hline & \multirow[b]{2}{*}{ Tolal Population } & \multicolumn{2}{|c|}{ Full-Time Enrolments } \\
\hline & & $\mathrm{N}$ & $\%$ of population \\
\hline $\begin{array}{ll}\text { Canada } & 1871 \\
\text { U.S. } & 1870\end{array}$ & $\begin{array}{r}3,500,000 \\
39,905,000\end{array}$ & $\begin{array}{r}1,561 \\
52,000\end{array}$ & $\begin{array}{r}0.044 \\
0.130\end{array}$ \\
\hline $\begin{array}{ll}\text { Canada } & 1901 \\
\text { U.S. } 1900\end{array}$ & $\begin{array}{r}5,300,(000 \\
76,504,000 \\
\end{array}$ & $\begin{array}{r}6,540 \\
238.000\end{array}$ & $\begin{array}{l}0.120 \\
0.310\end{array}$ \\
\hline $\begin{array}{l}\text { Canada } 1931 \\
\text { U.S. } 1930\end{array}$ & $\begin{array}{r}10,363,240 \\
123,188,000\end{array}$ & $\begin{array}{r}32,900 \\
1,101,000\end{array}$ & $\begin{array}{l}0.310 \\
0.890\end{array}$ \\
\hline $\begin{array}{l}\text { Canada } 1961 \\
\text { U.S. } \quad 1960\end{array}$ & $\begin{array}{r}18,238,647 \\
183,285,009) \\
\end{array}$ & $\begin{array}{r}113,729 \\
2.421,016\end{array}$ & $\begin{array}{l}0.620 \\
1.300 \\
\end{array}$ \\
\hline $\begin{array}{l}\text { Canada } 1981 \\
\text { U.S. } \quad 1980\end{array}$ & $\begin{array}{r}24,083,495 \\
226,709,873 \\
\end{array}$ & $\begin{array}{r}382,617 \\
7,097,958\end{array}$ & $\begin{array}{l}1.500 \\
3.100 \\
\end{array}$ \\
\hline Ca. & Increase in Enrolt & $871-1931$ & $\begin{array}{l}21.0 \% \\
21.2 \% \\
\end{array}$ \\
\hline
\end{tabular}

Note: American enrolment figures include junior colleges. For both countries, part-lime enrolments, which for the recent period are substantial, are excluded. In 1980, an additionat 4,999,000 American students were enrolled part-time. In Canada, the 1981 part-lime enrolment was 245,121 .

Sources: Bureau of the Census and Social Science Research Council, Historical Statistics of the United States, Colonial Times to 1957: A Statistical Abstract Supplement (Washington, 1960), 210-11; Statistical Abstract of the United States, 1993 (Washington: U.S. Department of Commerce, 1993); National Centre for Education Statistics, Digest of Education Sratistics, 1991 (Washing10n: U.S. Department of Education, 1991), 167; Statistics Canada, Historical Compendium of Education Statistics: Confederation to 1975 (Otawa, 1978), 208; Robin Harris, A History of Higher Education in Canada, 1663-1960 (Toronto: University of Toronto Press, 1976), 622-29; Statistics Canada, Universities, Enrolments and Degrees, 1984 (Onawa: Ministry of Supply and Services, 1986), 7. 
Table 2: Percent of Population Aged 20-24 Enrolled in Post-Secondary Education, 1930-31

\begin{tabular}{|l|c|}
\hline & $\begin{array}{c}\text { \% of population } \\
\text { Aged 20-24 }\end{array}$ \\
\hline Canada 1931 & 2.8 \\
\hline U.S. $\quad 1930$ & 11.3 \\
\hline
\end{tabular}

Sources: Konrad Jarausch, "Higher Education and Social Change: Some Comparative Perspectives," in The Transformation of Higher Learning, 1860-1930, ed. Konrad Jarausch (Chicago: University of Chicago Press, 1983), 16; Dominion Bureau of Statistics, Census of Canada, 194l, Vol. I (Ottawa, 1950), 314.

Table 3: Percent of Population Aged 18-24 Enrolled Full-Time in University, 1956-57 to 1984

\begin{tabular}{|l|c|c|}
\hline & Canada & U.S. \\
\hline $1956-57$ & 6 & 14 \\
\hline $1960-61$ & 8 & 15 \\
\hline $1967-68$ & 12 & 21 \\
\hline 1984 & 14.5 & 22 \\
\hline
\end{tabular}

Sources: Z.E. Zsigmond and C.L. Wentus, Enrolmem in Educational Institutions by Province, 1951-52 to 1980-81 (Ottawa: Economic Council of Canada, 1970), 38; Seymour Martin Lipset, Continental Divide: The Values and Institutions of the United States and Canada (New York: Routledge, 1990), 160).

Table 4: Total Post-Secondary Enrolment (Part-time and Full-time) as Percent of the Age Group 20-24, 1983 and 1988.

\begin{tabular}{|l|c|c|c|}
\hline & Canada & U.S. & Other Countries $^{\mathrm{a}}$ \\
\hline 1983 & 50.2 & 57.1 & 28.1 \\
\hline 1988 & 62.2 & 67.7 & 30.8 \\
\hline
\end{tabular}

Note: ${ }^{\text {a}}$ Other Countries: The average percentage for 14 other developed countries.

Source: Statistics Canada, Profile of Higher Education in Canada, 1991 (Ottawa: Ministry of Supply and Services, 1991), 36. 
At this point, however, an important caveat must be introduced. The American tefinition of college and university education, especially in the nineteenth century, was evidently more inclusive than that in Canada. First, a significant proportion of American "college" students were enrolled in "normal schools" for the trining of elementary school teachers. In $1870,10,000$ or 19.2 percent of the 52,000 American studems were registered in these institutions. In 1900, 76,000 or 32 percent of America's 238,000 students were so counted. ${ }^{22}$

In Canada, however, normal schools for the training of teachers were not included in the census category of post-secondary educational institutions, nor was a normal-school training required for teaching accrediation. Furthermore, teacher traning for secondary school teachers was fully integrated into Canadian universities only after the 1920s following the creation of faculties of education across the country, and elementary school teachers did not require post-secondary education on a unifom basis until the 1960s, though many teachers did in fact, voluntarily, obtatin university education before entering the profession.

This should not imply that American teachers were ineviably beter trained than those in Canada. By the 1890s, the majority of secondary school teachers in Ontario had obtained university degrees. ${ }^{23}$ Furlhermore many Canadian women who became elementary school teachers were laught in women's seminaries, academies, or conven schools, none of which was included in the Canadian definition of a university. In Ontasio, for example, by the 1840 s there were twelve women's academies, and others opened in subsequent years. ${ }^{24}$ While the majority either closed or eventually turned into elementary or secondary schools, their academic status in the early years was less easy to categorize. Some offered a range of education, a portion of which was similar to that in women's colleges in the United States in the $1850 \mathrm{~s}$ and $1860 \mathrm{~s}$. Even Vassar, an "elite" women's college in New York, was forced to provide basic education to a large number of "unevenly prepared" students who registered in its inaugural year of 1865." On the other hand, al though Alma College in St. Thomas, Ontario (founded in 1871 ) provided a level of education for women equivalent to that of a "junior college," it did not have higher cducational standing." As Helen

22. Burke, American Collegiate Populations, 216. Burke's total enrolment count for 1860 is higher $(61,000)$ than the 52,000 students counted by the census, and his 1900 figure $(252,000)$ is higher than the official figure of 238,000 . I have combinet his nomal-school figures with the official count to arive at these percentages.

23. R.D. Gidney and W.P.J. Millar, Inventing Secondary Education: The Rise of the High School in Nineteenth-Century Ontario (Montreal: McGill-Queen's University Press, 1990$), 300$.

24. Susan Housion and Alison Prentice, Schooling and Scholars in Nineteenth-Century Ontario (Toronto: University of Toronto Press, 1988), 43.

25. Johanna Selles-Roney, "A Realm of Pure Delight: Methodists and Women's Education in Ontario, 1836-1925" (Ph.D. diss., Universify of Toronto, 1993), 25.

26. Selles-Roney, "Manners and Morals?" $247-67$. 
Lefkowitz Horowity notes, largely in order to secure status, many American schools "had assumed the name 'college' quite indiscriminately," and were counted as such by statisticians. ${ }^{27}$ Had even a portion of these institutions been excluded in the count, the U.S. participation rate would have been lower than that indicated by the official statistics. Similarly, had Canada's "official" conception of higher education been more inclusive, then the post-secondary educational participation rate for the mid-to-late nineteenth century would have been more impressive than officially indicated.

The counting problem becones even more complex if one considers American academies, of which there were some six thousand in the $1850 \mathrm{~s}$. Official statistics on college and university errolments exclude these from the count, though according to Robert Church and Michael Sedlak, they were "fundanenlally similar" to colleges; both of fered "post-elementary" schooling to students ranging usually from ages 14 to $25 .^{28}$ Thus, including at least some academies as institutions of higher learning would have the effect of increasing the official participation rate in the late nineteenth century; but, as noted, excluding normal schools that were in fact counted, would have reduced it. Overlap between the curriculat of high schools and universities also occurred in Canada. As Gidney and Millar note for the 1860s in Ontario, "The work that constituted senior matriculation [in high schools] was also the work for the first year of university. ${ }^{29}$

While the distinctions between secondary and post-secondary education would become clearer by the early twentieth century in both countries, the comparative dilemma does not disappear. American statistics for most of the twentieth century also include "junior colleges" in the higher education category. These institutions typically offered the first two years of a four-year college degree, but did not themselves provide degrees. They grew significantly during the 1920s, providing a course of study whose first year, in all likelihood, was equivalent to senior matriculation, normally a high school year in Canada. ${ }^{30}$ To achieve better comparability, should senior matriculation have been counted as a college year in Canada? For the same reason, perhaps classical colleges in Quebec should have been so categorized as well. ${ }^{31}$

27. Helen Lefkowitz Horowitx, Alma Mater: Design and Experience in the Women's Colleges from their Nineteenth Century Beginnings to the 1930 s (New York: Alfred A. Knopf, 1984), 28, 56.

28. Rober1 L. Church and Michael W. Sedlak, "The Antebellum College and Academy," in Eduation in the United States: An Interpretive History (1976), reprinted in ASHE Reader on the History of Higher Education, 95.

29. Gidney and Millar, Inventing Secondary Education, 272.

30. Historical Statistics of the United States, the Colonial Period to 1957, 210.

31. Robin Harris, A History of Higher Education in Canada, 1663-1960 (Torono: University of Toronto Press, 1976), 24-25, 597. 
These statistical considerations lead to the following conclusions. However narrowly or broadly the term "post-secondary education" is defined, it is indisputable that the United States sent a significantly higher proportion of its population to college and university through the late ninetenth and much of the twentieth centuries. Official statistics imply that that gap was in place by 1870 and remained constant unil 1930. However, it is probable that by including normal-school enrolments in American college registrations, the U.S. participation rate was inflated, and that the actual enrolment gap between the two countries was not as stable between 1870 and 1930 as official statistics suggest. I would estimate that gap was somewhat lower than the threefold difference in the mid-10-late nineteenth century, and then increased somewhat to reach that point by 1930. It is important, then, to examine the circumstances which affected these trends both before and after 1870, and to this lask we now tum our attention.

\section{III}

In ways that historians are now rediscovering, religion mattered to North Americans throughout the nineteenth century. Canadians and Americans passionately proselytized on the frontier, built religious edifices in every community, and linked social progress and individual fate to the probity of righteous, usually Christian, living. ${ }^{32}$ Both societies, especially in the United States, absorbed the impact of evangelicalism, an energetic Christian movement with diverse, and at times conflicting, elements. The early history of higher education in the nineteenth century in both countries owes much to religious, particularly evangelical, activism.

In English-speaking British North America, Anglicans took the initiative in the area of higher education, founding King's College in Windsor, Nova Scotia, in 1790. Like its counterpart, King's College in New Brunswick (chartered as the "College of New Brunswick" in 1800), the institution adopted Oxford University as its model. The two colleges were designed to preserve British tradition, tain Anglican ministers, and cultivate the values of English "gentlemen." As in the British universities, religious tests and oaths essentially barred non-Anglicans from these institutions, inspiring the "dissenters," as we shall see, 10 create their own post-secondary educational pathways. ${ }^{33}$ In Upper Canada, a

32. For an overview see Mark A. Noll, A History of Christianity in the United States and Canceda (Grand Rapids: William B. Ecrdmans, 1992), chaps. 9 and 10.

33. Harris, A History of Higher Education, 27-29; W.B. Hamilon, in Canadian Eduedtion: A History, ed. J.D. Wilson, R. Stamp, L.P. Audet (Scarborough, Ont: Prentice-Hall, 1970), chaps. 5, 6; Laurence K. Shook, Catholic Post-Secondary 
Royal Charter for a third King's College was obtained in 1827, though the institution itself did not open until 1843. From the perspective of leading Anglicans like John Strachan, the denomination's first Bishop of Toronto, universities had a significant role to play in preserving social order and preparing society's future leaders. Strachan sought, but never achieved, exclusive provincial support for an Anglican university. Higher education in French Canada was overseen by the Catholic Church, which established Le Grande Seminaire du Québec in 1663, founded Université Laval in 1852, and directed more than three dozen classical colleges, industrial colleges, and seminaries throughout the province of Quebec in the nineteenth century.

Despite its privileged cultural and political status, Anglicanism would not dominate English Canada's educational landscape for long, though in French Canada, the educational authority of the Catholic church would endure well into the twentieth century. Reflecting the growing diversity of their immigrant population, the British colonies witnessed the rise of alternative religious communities armed with their own theological and educational agendas. Catholics outside of Quebec, where they comprised a minority of the population, sought to meet their clerical needs by establishing several colleges from the $1830 \mathrm{~s}$ to the 1850 s, primarily in Nova Scotia and Ontario. ${ }^{3.4}$ Broadly "evangelical" in their beliefs, Methodists, Baptists, Presbyterians, and others challenged traditional church hierarchies, and stressed instead the achievement of salvation through an individual's direct relationship with God. Faith, revivalism, and conversion, unconstrained by the medium of traditional church ritual and hierarchy, were, for evangelicals, a surer path 10 righteous living and a promising afterlife. ${ }^{35}$

Given the traditionalism of colleges and the selective basis of their constituencies, it was not inevitable that evangelicals would opt for this institutional and hierarchical form of educational raining. If religious salvation could be achieved outside the strictures of established churches, presumably higher learning or its equivalent could be conducted informally as well. Yet in both Canada and the United States, as their numbers and influence grew, evangelicals played a major role in extending higher education. Between 1829 and 1867, Methodists, Pres-

Education in English-Speaking Canada: A History (Toronto: University of Toronto Press, 1971), 8.

34. See Shook, Catholic Post-Secondary Education in English-Speaking Canada, Parts I-III.

35. Gauvreau, The Evangelical Century, 3-12. Also, Michael Gauvreau, "The Empire of Evangelicalism: Varieties of Common Sense in Scotland, Canada, and the United States," in Evangelicalism: Comparative Studies of Popular Protestantism in North America, the British lsles and Beyond, 1700-1990, ed. Mark A. Noll, David W. Bebbington, and George A. Rawlyk (New York: Oxford University Press, 1994), esp. 219. 
byterians, Baptists, and Congregationalists founded up to a dozen colleges from Newfoundland west to Ontario, though not all of these institutions survived. ${ }^{36}$ And in the United States, the period from 1800 to 1860 "produced the greatest boom in college growth in American history, the high tide of Christian influence in American higher education." 37

A number of factors explain the evangelical enthusiasm for higher education in Canada. "Moderate" evangelicals, like Methodist leader Egerton Ryerson, one of the founders in 1842 of Victoria College in Cobourg, Ontario, rejected special educational privileges for Anglicans, but shared with them a revulsion for revolution, and a belief in the need for civility and social order. This appeared particularly necessary in the wake of the 1837 rebellion in Upper Canada, and for Ryerson, college education could be a source of both cultural unity and social progress. With other Christian educators, he believed in "the primacy of theology in education and culture, and [in] the premise that Christian belief functioned in a world defined by the advance of scientific knowledge. ${ }^{38}$ Ryerson represented that important threadi of Canadian Methodism that linked religious diversity, in a Christian context, with loyalism to the British crown. Colleges had a place in this world-view, in that they fostered "sound learning and moral conduct.",39

Furthermore, as evangelical Christianity more thoroughly entered the social mainstream, its advocates became aware of the social status associated with university credentials. Methodists did not require ordained ministers to hold college degrees, but increasingly this formal training system became more common. According to Michael Gauvreau, "While preaching power remained the crucial element of the itinerant's training, more rigorous courses of theological study were provided, stressing better preparation in systematic theology and church history....Christian experience and the practical requirements of a Christian life shaped the Methodist ideal of learning in the colleges., ${ }^{40}$

Even the activist and populist orientation of evangelicalism found an outlet in colleges and universities. Though never reaching the frequency and degree of intensity in American colleges, religious revivals were common on Canadian campuses at mid-century. These episodes involved days, sometimes weeks, of prayers, confessions, and conversions among students. Evangelicalism could inspire such engagement because, as Brian McKillop notes, "it had the capacity

36. D.C. Masters, Protestant Church Colleges in Canada: A History (Toronto: University of Toronto Press, 1966), chap. 3.

37. William C. Ringenberg, "The Old Time College, 1800-1865," in Making Higher Education Christian: The History and Mission of Evangelical Colleges in America, ed. Joel A. Carpenter and Kenneth W. Shipps (Grand Rapids: William B. Eerdmans, 1987), 78 .

38. Gauveau, The Evangelical Cenury, 46.

39. Ibid., 50 .

40. Ibid., 48 . 
to affect one's view of almost every aspect of life: character, conduct, vocation, the role of women, the place of the fanily, philanthropy, and mission work. In Ontariol it molded the character of higher education."

In the Maritime provinces, evangelicalism, under the formidable leadership of Henry Alline, had a powerful impact, particularly in Nova Scotia in the late eighteenth century. Following the war of 1812, as in Upper Canada, the radical strain of the movement was tempered as the influence of British Wesleyan immigrants outweighed that of American Methodist preachers. The former "put greater stress on formal traning, on decorum in worship, and on a more lightly disciplined approach to spiritual life." ${ }^{42}$ Colleges and miversities, including Mount Allison in Sackville, New Brunswick (Mcthodist), Acadia in Wolfville, Nova Scotia (Baptist), and Dalhousie in Halifax (non-denominational wilh strong Presbyterian links), provided advanced schooling in formal sellings while retaining an evangelical flavour, including periodic student revivads. ${ }^{43}$ The ScottishPresbyterian intluence in Alantic Canada also inspired interest in extending education. $^{44}$

Thus religious commiomens, both traditional and evangelical, and both Protestant and Catholic, stimulated the extension of higher education in Canada in the period before 1870 . Religious tension, cmiously, also led to the founding of new universities. The University of Montreal was initiated (as a Laval affiliate) in 1876 , in part out of the conflict between the ultranontanist orientation of Laval and the alternative gallican Catholic movement in Montreal. 45 The creation of the non-denominational University of Torono in 1849 reflected not a victory for secular values, but an attempt to forge a workable educational compromise among

41. McKillop, Matters of Mind, 95. See also Mashall, Secularizing the Faith, 32; Masters, Protestant Church Colleges in Canada, 6; George Rawlyk, "Protestant Colleges in Canada: Past and Future," in The Seculdrization of the Acudemy, ed. Marsden and Longficld, 282. On the United States, see Ken, Rites of Passisuge, 66, 74.

42. Not1, A History of Christianity in the United States and Canada, 263.

43. Barry M. Moody, "Breadth of Mind: The Baptists and Acadia College," in Canadian Baptists and Christian Higher Edwation, ed. G.A. Rawlyk, 14.

44. John G. Reid, "Beyond the Democratic Infelled: The Scotish Example and University Reform in Canada's Maritime Provinees, 1870-1933," in Youth, University, and Canadian Society: Essays in the Social History of Higher Edweation, ed. Axelfod and Reid, 275-300; P.B. Waite, The Lives of Dalhousie University, 1818 . 1925, Volume One (Montreal: MeGill-Queen's University Press, 1994), 94; 3. Anne Wood, "The Significance of Evangelical Politics in the Construction of State Schooling: A Case Study of the Pictou District, 1817-1866," Acaliensis XX, 2 (Spring 1991): $62-85$.

45. Harris, A History of Higher Education in Canadu, 107-8; John Webster Gram, The Church in the Canadian Era: The First Cenury of Confederation (Tomonto: McGraw-Hill Ryerson Lid, 1972), 71-72. 
competing Christian denominations. Through its curriculum, its rules governing student deportment, and its appointment of presidents, a Christian aura pervaded the University of Toronto into the late nineteenth century. ${ }^{46}$ Similaty, Dalhousie University's long-delayed opening in 1863 could be explained in part by the cooling of religious tensions in Nova Scolia between Presbyterians and their religious competitors and among Presbyterians themselves. ${ }^{47}$ In Canada, higher education was one arena for the contest and rough consensus forged between a conservative religious culture based on social "order" and an alternative one based on individual "experience." 48

As valued as it was by its proponents, higher education was available to a relatively small number of Canadian youth. In 1871 , the largest university in the Maritimes, Dalhousie, had only 87 students, and the largest in Canada, McGill, had only 323 . For virually every institution, material viability was a constant preoccupation. Funding shortages plagued Canada's universities, limiting their growth and forcing them to function, if at all, in an environment of scarcity. Herein lay a clue to the limited development of Canadian higher education for most of the nineteenth century. Provincial government support for universities was intermittent and unreliable. Denominational institutions relied primarily on donations from their respective churches and from private individuals, a minority of whom were wealthy, the vast majority of whom were not. Funding from the Catholic Church helped kep Laval University viable-- though far from prosperous-- through this period; ${ }^{49}$ in English Canda, the situation was even less centain. Bishop's University, which had the support of the Anglican business and clerical elite of Quebec's eastern townships, nevertheless ran into economic difficulty in the recession of 1843, the year it plamed to open, and by 1847 had a debt of more than one thousand pounds. ${ }^{50}$ Provincial government gants to denominational colleges were ended in Ontario in 1868, and in Nova Scotia in 1881. The latter act forced the closure of St. Mary's College for twenty-1wo years, and seriously hampered the operation of St. Francis Xavier College, Nova Scotia's other Catholic institution of higher education. ${ }^{51}$ The economic fortunes of universities and colleges undulated with the fate of regional economies.

McGill University, the bestendowed institution in Canada, benefited from Monteal's enviable location as a tansporation and commercial hub in Canada's

46. McKillop, Matters of Mind, chap. 4.

47. Waite, The Lives of Dalhousie University, chap. 4.

48. Westfall, Two Worlds, 267.

49. Harris, A History of Higher Education in Canada, 107-8.

50. Christopher Nicholl, Bishop's University, 1843-1970 (Montreal: McGill-Queen's University Press, 1994), 26-27.

51. Shook, Catholic Post-Secondary Education in English-Speaking Cunada, 62, 77. 
burgeoning national economy, and elicited support from a small number of wealthy businessmen. ${ }^{52}$ Canadian Baptists, who sought to establish and sustain colleges in both Nova Scotia and central Canada, and who, on principle, opposed any state aid, were finally rewarded by a $\$ 900,000$ donation from businessman William McMaster, a gift that made possible the establishment of McMaster University in $1887 .{ }^{53}$ Dalhousie was able to develop in the late nineteenth century without state support on the basis of a $\$ 350,000$ donation from George Munro, a Nova Scotian who becane a prosperous New York publisher. ${ }^{54}$ For the most part, the religious colleges received little or no public funding and depended for their income on "small contributions." 55

On the basis of local support, Methodists in New Brunswick and Nova Scotia managed to keep Mount Allison University afloat, and its expansion in the last part of the century was "inseparable from the prosperity which had accompanied the coming of the Intercolonial Railway and the initiation of the National Policy." ${ }^{, 56}$ But when the Maritime economy lost much of its shipping and manufacturing base in the early twentieth century, higher education felt the impact. According to a study conducted by the Carnegie Commission in 1921 , the region's universities were found to be suffering from "small endowments, underpaid faculties, poor library collections and inadequate physical facilities.",5?

An innovative approach to meeting the practical and political challenges of higher education involved the scheme of universily federation. Unable to sustain themselves on the basis of private or denominational suppon, a number of colleges and universities, particularly in Ontario, surrendered their autonomy to the (non-denominational) University of Toronto. The formerly denominational colleges would continue to teach theology and arts, but their students would receive University of Toronto degrees. By the first decade of the twenticth century, Trinity, St. Michael's, Knox, Vicloria, and Wycliffe participated in this arrangement. Queen's University retained its independence as a Presbyterian-led institution, but by 1912 practical exigencies compelled it to reorganize itself as a non-denominational institution, which entitled it to badly needed provincial

52. Stanley B. Frost, McGill University: For the Advancement of Leaming, Vol. , 1801-1895 (Montreal: McGill-Queen's University Press, 1980), 35-36, 239-44; Harris, A History of Higher Education in Canada, 106.

53. See G.A. Rawlyk, "A.L. McRimmon, H.P. Whidden, T.T. Shields, Christian Higher Education, and McMaster University," in Canadian Baptists and Christian Higher Education, ed. G.A. Rawlyk, 31-32. Refusing state aid was a Baptist principle applied less vigorously in Nova Scotia than in Ontario: Acadia received provincial government funding in 1843. See Waite, The Lives of Dalhousie University, 60-62.

54. Harris, A History of Higher Education in Canada, 105.

55. Masters, Protestant Church Colleges in Canada, 15.

56. John G. Reid, "Mount Allison College: The Reluctant University," Acadiensis 10, 1 (Autumn 1980): 44-45.

57. Ibid., 36 . 
funding. Similarly, following a period of continuous economic crisis, the University of Western Ontario became independent from the Church of England in 1908. From the outset in 1877 , the federation arrangement was the basis for the organization of higher education in the new province of Manitoba. Most religious organizations would have preferred to sustain independent universities. The reality was that in English-speaking Canada, this proved to be economically unfeasible. This uncertain environment constrained the growth of Canadian higher education throughout most of the nineteenth century.

\section{Table 5: Religious Adherents by Denomination, Canada, 1871}

\begin{tabular}{|c|c|c|}
\hline & $\mathrm{N}$ & $\%$ \\
\hline Anglican & 504,392 & 14.00 \\
\hline Baptist & 244,373 & 6.80 \\
\hline Jewish & 1,223 & 0.03 \\
\hline Lutheran & 38,226 & 1.00 \\
\hline Roman Catholic & $1.536,733$ & 43.00 \\
\hline Congregationalist & 21,956 & 0.60 \\
\hline Melhodist & 582,362 & 16.30 \\
\hline Presbyterian & 578,185 & 16.20 \\
\hline Other denominations & 71,922 & 2.00 \\
\hline All denominations ${ }^{\mathrm{a}}$ & $3,579,782$ & 100.00 \\
\hline
\end{tabular}

Note: "Excludes 109,475 people, mostly Indians, for whom information on religious denomination is unavailable.

Source: Census of Canada, 1941, Vol. 1, 289.

The situation was somewhat different in the United States. Given the particularly large component of religious "dissenters" in its population (primarily Baptists and Methodists: see Table 6), nineteenth-century America was especially vunnerable to the evangelical religious movements. As Nathan Hatch notes, at the beginning of the century, the traditional religious denominations (themselves formerly "dissenters")in the United States-the Congregationalist, Presbyterian, and Episcopalian churches - "lay in such disarray that movements such as the Methodists, Baptists and Christians were given free rein to experiment,.,58

58. Nathan O. Hatch, The Democratization of American Christianity (New Haven and London: Xale Universily Press, 1989$), 59$. 


\section{Table 6: Religious Adherents by Denomination, United States, 1776 and 1850}

\begin{tabular}{|l|r|r|}
\hline & \multicolumn{1}{|c|}{1776} & \multicolumn{1}{|c|}{1850} \\
\hline Congregationalists & $20.4 \%$ & $4.0 \%$ \\
\hline Episcopalians & $15.7 \%$ & $15.7 \%$ \\
\hline Presbyterians & $19.0 \%$ & $11.6 \%$ \\
\hline Baptists & $16.9 \%$ & $20.5 \%$ \\
\hline Methodists & $2.5 \%$ & $34.2 \%$ \\
\hline Catholics & $1.8 \%$ & $13.9 \%$ \\
\hline
\end{tabular}

Source: Roger Finke and Rodney Stark, The Churching of America, 1776-1990: Winners and Losers in Our Religious Economy (New Brunswick, N.J.: Rutgers University Press, 1992), 55. The American census did not record the religious denominations of the population. The above figures evidently come from membership lists provided by denominations themselves. For a fuller discussion, see Finke and Stark, 6-7.

The former groups would subsequently regain a good deal of their vitality, but they would never again dominate the religious marketplace. ${ }^{59}$

The Second Great Awakening, from the tum of the nineteenth century to about 1835 , enabled evangelicals to expand their constituencies significantly, and universities and colleges were an integral part of the mission process. As William Ringenberg notes, "Denominational representatives together with local officials established colleges in the newly opened regions to train future ministers and to indoctrinate the aspiring leaders of the society with evangelical verities., 60 Before 1820 almost seventy percent of America's colleges were sponsored by Congregationalists, Presbyterians, and Episcopalians. By the Civil War, Methodists and Baptists staffed a third of the nation's institutions of higher learning; the three large colonial denominations, another third; and other religious groups another ten percent. ${ }^{61}$ Like their Canadian counterparts, the Methodist and Baptist churches increasingly sought the prestige that prominent institutions might provide. "They built substantial sanctuaries, installed organs, rented out

59. Roger Finke and Rodney Stak, The Churhing of America, 1776-1990: Winners and Losers in Our Religious Economy (New Brunswick, N.J.: Rulgers University Press, 1992), chap. 3.

60. Ringenberg, "The Old Time College," 79. See also Rudolph, The American College and University: A History, 55-58.

61. Noll, A History of Christianity, 230. 
pews, and demanded college-trained ministers... and they directed their finest efforts toward building educational institutions, "62 Colleges, as Lawrence Cremin explains, were "widely seen...as centres of religious leadership and sources of public piety, and therefore as ancillary to the church in the preservation of a free society.

The significant expansion of Catholic higher education in the United States should also be noted. By 1850 Roman Catholic colleges accounted for ten percent of all institutions of higher education. ${ }^{64}$ Of the forty-1wo Catholic colleges founded between 1786 and 1849 , ten ulimately achieved permanent standing. And of twenty-four Catholic colleges founded between 1850 and 1870, twenty. three survived. ${ }^{65}$ While not technically evangelical in its theological roots, in the context of American society there was, as Finke and Stark note, an evangelical thrust to Catholicism "similar to that of the upstart Protestants - the Baptists and Methodists. The Catholics aggressively marketed a relatively intense, otherworldly religious faith to a growing segment of the population. Besides offering familiar liturgy, symbols, and saints, the Catholic Church also emphasized personal renewal through devotional activities and in effect produced its own brand of revivalism, ${ }^{66}$ thus enhancing their appeal among the legions of immigrants in the last half of the nineteenth century. The construction of parish schools, academies, seminaries and colleges, built without public funding, indicated both the commitment of the Church's followers, and their search for respectability and social advancement in American society. ${ }^{67}$

While there were numerous false starts and failures among religious colleges in the United States, in general they were able to draw upon a richer pool of resources, both public and private, than was the case in Canada. As David Potts notes,

Antebellum colleges can now be seen as broadly based local enterprises, deeply rooted in the economic and cultural life of hundreds of towns, counties, and surrounding areas in states extending from the east coast westward through the Mississippi Valley. Access to a college education, it appears, was relatively easy compared to the years before 1800 , and an increasing number of students from humble family backgrounds

62. Hatch, The Democratization of American Christianity, 195; Finke and Stark, The Churching of America, 155, 160.

63. Lawrence Cremin, American Edacation: The National Experience, 1783-1876 (New York: Harper and Rowe, 1980), 402.

64. Burke, American Collegiate Populations, 22; Noll, A History of Christianity, $351-52$.

65. Edward J. Power, Catholic Higher Education in America: A History (New York: Meredith Corporation, 1972), 49,61.

66. Finke and Stark, The Churching of America, 115.

67. Ibid, , 140-44. 
were enrolling and making their presence felt....Especially interesting is the discovery that a constantly increasing proportion of potential college students in the national population is found to be enrolling at these institutions during the four decades preceding the Civil War. 88

Pots' analysis of the growth of Baptist-led colleges illustrates the building process. Typically, local business leaders would promote the spiritual and practical virtue of a college, lead fund-raising campaigns within the community while donating resources of their owm, ensure that non-Baptists were welcomed in the institutions, and promote the economic spin-ofs to the community arising from the presence of fee paying students. ${ }^{69}$ Frequently, lowns competed for the establishment of new colleges, and others fought to prevent colleges from relocating, believing that those communities endowed with higher education were "more altractive than their less sophisticated neighbors,"

Nor did state and local governments stand in the way of this growth. "Few entrepreneurial ventures were stopped because the state refused to grant a charter or because it effectively regulated the venture, once established." "7T By contrast, most Canadian communities had neither the population base nor the resources to engage in the kind of rivalry and institution-building that fuelled the development of American higher education. That a higher proportion of the American population lived in urban centres-25.7 percent in 1870 compared to 18.3 percent in Canada a aided the expansion of local colleges, which, as Lawrence Cremin notes, were "sponsored and supponted by the communities that patronized and sustained them.",

In the period following the civil war, the private resources available to American colleges and universities were even more impressive. As industrial growth in the U.S. reached unprecedented levels, new fortunes were accumulated by successful entrepreneurs. Inspired in part by religious motives and in part by the manpower training needs of a changing economy, businessmen provided

68. David B. Pot1s, "College Ethusiasms as Public Response, 1800-1860," Hamard Educational Review 47, 1 (Feb, 1977): 31. See also Allmendinger, "New England Students and the Revolution in Higher Education," 65-71.

69. Pots, "College Enthusiasms," 32-24.

70. Ringenberg, "The Old Time College," 81 . On early developments in Massachusetts, see also Richard Freeland, Academia's (rolden Age: Universities in Massachusetts, 1945-1970 (New York: Oxford Universify Press, 1992), 21-22.

71. Church and Sedlak, "The Antcbellum College and Academy," in ASHE Reader on the History of Higher Edwation, 97.

72. Cremin, American Education: The National Experience, 1783-1876,402. Statistics on urbanization are drawn from Raymond A. Mohl, The New City: Urban America in the Industrial Age (Arlinglon Heights, Ill.: Harbour Davidson, 1985), 8, and A.J. Artibise and G.A. Stelter, "Urbanization," in The Canadian Encyclopedia, Vol. III (Hurtig: Edmonton, 1985), 1887. The Canadian figure is for 1871. 
substantial gifts to educational institutions. Boston University (Methodist) was founded in 1869 with a gift of $\$ 1,700,000$ from Isaac Rich, to that date the larges educational contribution yet made by an American. ${ }^{73}$ Banker Johns Hopkins left $\$ 3,500,000$ to the university that would bear his name. Similarly, Comelius Vanderbilt gave $\$ 1,000,000$ to a new southern college. Transportation magnate Leland Stanford left $\$ 20,000,000$ to Stanford University, and John D. Rockefeller provided $\$ 45,000,000$ to a Baptist university in Chicago. In total, between 1878 and 1898, private donors contributed $\$ 140,000,000$ to American colleges and universities, helping facilitate the considerable expansion which occurred in those years. $^{7.4}$

Federal government financial support was provided to new "land gran" universities through the Morrill Act of 1862 and the second Morrill Act of 1890 , legislation which led eventually to the establishment of state colleges throughout the nation. ${ }^{75}$ Indeed, as Frederick Rudolph notes, American universilies received far more government support in the nineteenth century than implied by the "romantic" myth of the "self-reliamt" university. In both the colonial and antebellum eras, state aid to a number of importan institutions, including Harvard, Yale, Columbia, and Princeton, was considerable and vital. ${ }^{76}$ While state funding of higher education would ulimately prove to be of critical importance to the growth of Canadian universities, there was no nineteenth-century equivalent of the Morrill Act north of the border. In Canada, education was a provincial as opposed to federal responsibility; institutions of higher learning thus depended upon impecunious provincial governments for any monetary aid that might come their way, which, with few exceptions, was minimal until well into the twentieth century.

The combination of evangelical fervour, private capital, and state suppon had one additional consequence which distinguished American from Canadian university development: the establishment of private women's colleges. Initia-

73. Freeland, Academia's Golden Age, 26.

74. Mark A. Noll, "Christian Colleges, Christian Worldviews, and an Invitation to Rescatch," in The Christian College: A History of Protestant Higher Education in America, ed. Willian C. Ringenberg (Rapids, Mich.: William B. Eerdmans Publishing Co., 1984), 25-26. For an overview of private philanthropy to U.S. universities, see Merle Curti and Roderick Nash, Philanthropy in the Shaping of American Higher Education (New Brunswick, N.J.: Rutgers University Press, 1965), esp. chap. 3.

75. John Brubacher and Willis Rudy, Higher Education in Transition (New York: Harper and Row, 1976), 62-64.

76. Rudolph, The American College and Unversity: A History, 185-89. See also George M. Marsden, who writes that "until the Civil War, the vast majority of American colleges were founded by churches, often with state or community tax support": "The Soul of the American University: An Historical Overview," in The Secularization of the Academy, ed. Marsden and Longfield, 10. 
tives for the "higher" education of women took the form of female seminaries, a number of which opened in the late eighteenth century, and the most lamous of which was Mount Holyoke, established in Massachusets in $1836 .{ }^{77}$ As indicated above, these seminaries resembled Canadian academies for women, but unlike the Canadian case, many of the American institutions evolved into private colleges for women. Support for women's participation in higher education was fuelled by the burgeoning evangelical movement, whose ethos of "spiritual equality before God" justified, for many, the pursuit of equality of educational opportunity as well. ${ }^{78}$ The willingness of a growing number of colleges to admit fee-paying women students in the 1860) resulted also from the shortage of male students during the Civil War. Including private and public institutions, women constituted 21 percent of the undergraduate student body in 1870 and 32 percent by $1880{ }^{79}$

Still, the struggle for full female access to higher education faced many obstacles in the United States. When Harvard medical professor Edward H. Clate published his influental book, Sex in Education, in 1874, asserting that "identical education of the sexes is a crime before God and humanity" which "emasculates boys and stunts girls," his arguments were embraced by opponents of advanced education for women. Those who abhorred co-education found separate schooling for the sexes a lesser evil and to some degree the establishment of private colleges for women muted their resistance.

The creation of these institutions was possible only because philanthropists had the resources to support them. In New York and Massachusetts, privately endowed higher education for women flourished. Elmira College was founded in 1852 by Simon Benjamin, a promoter of canals, railroads, and industry. ${ }^{81}$ The best-known women's college, Vassar, was initiated in 1865 by Matlew Vassar, a successful-and religious-brewer, who provided the new institution with an endowment of $\$ 400,000)^{82}$ The first woman to endow a private college was Sophia Smith, who used her vast inheritance 10 create Smith College, which opened in 1875. Henry Durant, a leading corporate atomey and pious evangeli-

77. Ann D. Gordon, "The Young Ladies' Academy of Philadelphia," in Women of America: A llistory, ed. Cawol Ruth Berkin and Mary Beth Norton (Boston: Houghion Mifflin Co., 1979); Horowit, Alma Mater, chaps. 1, 2.

78. David F. Noble, A World Without Women: The Christian Clerical Culure of Western Science (New York: Oxford University l'ress, 1993), 250.

79. Patricia A. Graham, "Expansion and Exclusion: A History of Women in American Higher Education," in ASHE Reader on the History of Higher Education, 417; originally published in Signs 3,4 (Summer 1978): 759-73.

80. Cited in Lapierre, "The First Generation," 276.

81. Noble, World Without Women, 266; Curti and Nash, Philanthropy in the Shaping of American Higher Edacation, chap. 5.

82. Ringenberg. The Christian College: A History of Protestan Higher Education in America, 95. 
cal in Boston, founded Wellesley College, also in 1875. Similar initiatives were taken during this period elsewhere in the country. ${ }^{83}$ In 1870 , fully 59 percent (or 6,500) of female American students were enrolled in women's colleges. The proportion of women attending co-educational institutions subsequently grew towards the end of the century; still, in 1900, 29 percent of women (24.4 thousand) were enrolled in all-women's colleges. ${ }^{84}$

In Canada, the debate over higher education for women was equally intense and was also influenced by the followers of biological determinists like Edward Clarke. Two leading educators, William Dawson, the principal of McGill, and Daniel Wilson, the president of the University of Toronto, both opposed co-education, favouring instead separate education designed to fit the supposedly domestic orientation of female nature. Notably, by contrast, Mount Allison University, a Methodist-led institution, admitted women in 1862, the first Cana" dian university to do so.

Efforts to meet the educational needs of women by creating female colleges in Canada floundered. Mount St. Vincent, an all-women's Catholic academy in Halifax, did obtain degree-granting status in 1925, but lacked university standing until then. In 1908, L'école de'enseignement supérieur pour les jeunes filles was established by the Congregation of Notre Dame in Montreal as a Laval affiliate but retained the status of a classical college. ${ }^{85}$ Post-secondary educational and professional taining opportunities for women in Quebec were severely limited until well into the twentieth century, ${ }^{86}$ Arising in part from the hostility to co-education for medical students, two women's medical colleges were established in Ontario in the $1880 \mathrm{~s}$, but inadequate funding led to their early closure in 1892 and $1905 .{ }^{87}$ Owing to the expense, efforts to create a women's college

83. Lynn D. Gordon, Gender and Higher Education in the Progressive Era(New Haven: Yale University Press, 1990), 149; Horowitz, Alma Mater, chaps. 1-5; Noble, World Without Women, 257; Thomas Woody, A History of Women's Education in the United States (1929; reprint, New York: Octagon Books Inc., 1966), 150-55.

84. Gordon, Gender and Higher Education, 7.

85. Harris, A History of Higher Education in Canada, 219; Marta Danylcwycz, Taking the Veil: An Altemative to Marriage, Motherhood, and Spinsterhood in Quebec, 1840-1920 (Toronto: McClelland and Stewart, 1987), 146-51. In 1925, it was renamed Collège Marguerite-Bourgeois.

86. Women were not admitted to the Quebec bar for the practice of law until 1941. See Danylewycz, Taking the Veil, 57, for this and other examples.

87. Lykke de la Cour and Rose Shenin, "The Ontario Medical College for Women, 1883-1906: Lessons from Gender-Separatism in Medical Education," in Rethinking Canada: The Promise of Women's History, ed. Veronica Strong-Boag and Anita Feldman (Toronto: Copp Clark, 1991), 206-14; Peter E. Paul Dembski, "Jenny Kidd Trout and the Founding of the Women's Medical Colleges at Kingston and Toronto," 
within McGill University filled. 88 There and elsewhere women were eventually admitted to male-dominated institutions, in large measure because the costs of sejarate or segregated education were prohibitive. Financial factors were one, though not the only, barrier in the failed attempt to create a "Vassar of the Dominions" in Hamidon in the late ninetenth century. ${ }^{89}$ The private resources, let alone the government commitments, required 10 mount and sustain such institutions were lagely lacking in Canada. As Daniel Wilson observed in 1884, the Ontario Legislature had rejected the idea of a college for women in the province. "Economy...is undoubtedly in favour of the present plan. Co-education is cheap." .90

Just as the combination of religious initiatives and private wealth fed to the building of women's colleges in the United States, so 100 it accounted for the creation of Black colleges in the late nineteenth and early twentieth centuries. Some forty such colleges were established in the quarter-century following the Civil War, with the major organizing role taken by the American Missionary Association of the Congregational Church, augmented by the Methodist Episcopal and Baptist churches. The segregation of American schooling, including higher education, was reinforced by the Second Morrill Act of 1890 , and Blacks thus continued to reguire their own graduates to serve as ministers and schoolteachers. State and federal aid to Black colleges, while permissible under the land grant system, was severely limited, and these institutions remained both badly underfunded and less academically prestigious than their white counterparts. The missionary societies of the northern denominations provided most of the philanthropic support throughout the nineteenth century; by the early twentieth century, a number of foundations made signilicant contributions to Black colleges. The largest came from the General Education Board founded by John D. Rockefeller in 1903 , which by 1932 had contributed more than $\$ 32$ million to Black colleges, though most of this went 10 a limited number of institutions. In the mid-twentieth century, the United Negro College Fund became the most significant fund-raising agency for Black colleges, providing more than ten million dollars annually by 1960. Thus, for the century following the Civil War, higher education for Blacks was essentially "separate and unequal" to that for whites. Whatever marginal educational opportunities existed in that era flowed largely from the combination of religious missions and private patronage aid which enabled a small component

Ontario History 72, 3 (Sept. 1985): 183-206.

88. Margaret Gillen, We Walked Very Warily: A History of Women at McGill (Montreal: Eden Press Women's Publications, 1981), chaps. 3-4.

89. Bert Den Boggende, "The Vassar of the Dominions: The Wesleyan Female College and the Project of a Women's University, 1861-1897," Ontario History 85, 2 (June 1993): $95-115$.

90. Lalierre, "The Firsi Generation," 100. 
of the Black population to participate in higher education in the early twentieth century. ${ }^{91}$

By the mid-nineteenth century, aditional religious denominations had already provided some ationale for the existence of higher education, inspired largely by the need for trained clergy. But in both countries, evangelicalism subsequently spurred the development of post-secondary education. The different configuration of the religious communities in the United States especially strengthened the activist and populist strain of evangelicalism. And the relative abundance of private capital made possible the lauger scale of construction of higher educational institutions, for both women and men, south of the border, a pattern which continued into the early twentieth century. While comparable aggregate statistics are not available for the late nineteenth century, Tables 7 and 8 indicate the relative importance of private aid to higher education. In 1930, in Canada, 29 percent of university income was raised from private sources; in the United States, 43 percent was so obtained. In the decades that followed, Canadian dependence on government funding increased more rapidly than that in the United States, a trend which also underlined the comparative wealth of the American private corporate sector. ${ }^{92}$

91. Ringenberg, The Christiun College: A History of Higher Education in America, 85-91. See also Kujovich, "Equal Opportunity in Higher Education and the Black Public College," 226-356; Frank Bowles and Frank A. De Costa, Between Two Worlds: A Profile of Negro Higher Education (New York: MoGraw Hill Book Company, 1971); Brubacher and Rudy, Higher Edacation in Transition: A History of American Colleges and Universities, 1636-1976, 74-83; Lawrence Cremin, American Education: The Metropolitan Experience, 1876-1980 (New York: Harper and Rowe, 1988), 119-22; Curti and Nash, Philanthropy in the Shaping of American Higher Education, chap. 8.

92. For a discussion of the importance of American philanthropic support to higher education in easten Canada, see John G. Reid, "Health, Education, Economy: Philanthropic Foundations in the Allantic Region in the 1920 s and 1930s," Acadiensis 14, 1 (Autumn 1984): 64-83. See also Martin Trow, "Origins and Development of Federalism in American Higher Education," in Higher Education in Federal Systems, ed. D. Brown, P. Cazalis, G. Jasmin (Kingston, Ont.: Queen's University Institute of Governmental Relations, 1992), $71-73$. 
Table 7: Sources of Funds of Universities in Canada as Percent of Operating Expenditures"

\begin{tabular}{|l|r|r|r|r|}
\hline & Fees & \multicolumn{1}{|c|}{$\begin{array}{c}\text { Gov't } \\
\text { Grants }\end{array}$} & Other & $\begin{array}{r}\text { Total } \\
(\$ 000)\end{array}$ \\
\hline $1930-31$ & $23.0 \%$ & $47.8 \%$ & $29.0 \%$ & 14,437 \\
\hline $1970-71$ & $15.6 \%$ & $76.0 \%$ & $8.2 \%$ & $1,223,947$ \\
\hline
\end{tabular}

Notes: "Excludes capital funding.

bncludes such categories as private gifts, endowment income, income from auxiliary enterprises, and miscellaneous sources.

Source: Calculated from Statistics Canada, Historical Compendium of Education Statistics: From Confederation 10 1975 (Ottawa, 1978), 250.

Table 8: Sources of Funds, Institutions of Higher Education, United States, as Percent of Operating Income ${ }^{a}$

\begin{tabular}{|l|r|r|r|r|}
\hline & \multicolumn{1}{|c|}{ Fees } & \multicolumn{1}{|c|}{$\begin{array}{c}\text { Gov't } \\
\text { Grants }\end{array}$} & Other & \multicolumn{1}{c|}{$\begin{array}{c}\text { Total } \\
(\$ 000 \mathrm{~s})\end{array}$} \\
\hline $1929-30$ & $26.0 \%$ & $31.0 \%$ & $43.0 \%$ & 554,511 \\
\hline $1969-70$ & $20.5 \%$ & $43.0 \%$ & $36.5 \%$ & 21.515 .242 \\
\hline
\end{tabular}

Notes: ${ }^{a} E x c l u d e s ~ c a p i t a l$ funding.

bncludes such categories as private gifts, endowment income, in come from auxiliary enterprises, and miscellaneous sources.

Source: Calculated from National Centre for Education Statistics, Digest of Education Statistics (Washington: U.S. Department of Education, 1982), 139. 
IV

If the supply of resources for the development of higher education was greater in the U.S. than Canada, so too was the demand for graduates in the early twentieth century, a factor which also helps explain the continuing gap in participation rates in the two countries after 1870 .

As noted, women constituted a far higher proportion of the university undergraduate population in the United States than in Canada. In 1900, 11 percent of Canadian university students were women compared to 36.8 percent in the United States. In 1930, women constituted 23.7 percent of the full-time student population in Canada and 43.7 percent in the United States.

In both countries, women graduates from the late nineteenth century to the beginning of World War Il were less likely than their male counterparts to engage in full-time careers, and many of those who joined the labour force left it, frequently by compulsion, once they married. Restrictive entry conditions, including quotas, confronted women in the professions and public services of both countries. ${ }^{93}$ Despite these obstacles, a growing percentage of women in Canada and the United States were able to enter the labour force at the turn of the century. In both countries, schoolteaching was a major employer of women. Significantly, a higher proportion of U.S. women worked outside the home. In 1900 , women constituted 18 percent of the American labour force compared to 13.3 percen in Canada. In 1930, 22 percent of the American labour force consisted of women compared to 17 percent in Canada. ${ }^{94}$

The higher demand for women in the burgeoning private sector in the United States is one probable explanation for this gap. Clerical work expanded tremendously in this era, and while one did not require a university degree for such employment, many university graduates held such positions. Increasingly, women in the "progressive" era combined employment with family life. Some

93. On Canada, see Alison Prentice el al, Canadian Women: A Hisiory (Toronto: Harcour1 Brace Jovanovich, 1988), 129-35 and passim; Graham S. Lowe, Women in the Administrative Revolution (Toronto: University of Toronto Press, 1987), 72. On the United States, see Rosalind Rosenberg. "The Limits of Access: The History of Co-education in America," in Women and Higher Education in America, ed. John Mack Faragher and Florence Howe (New York: W.W. Norton and Co., 1988), 107-29; and Barbara Sicherman, "College and Careers: Historical Perspectives on the Lives and Work Patterns of Women College Graduates," in ibid.

94. Canada, Department of Labour, Occupational Trends in Canada, 1891 to 1931 (Ottawa, 1939); Dominion Bureau of Statistics, Occupational Trends in Canada, 1931 to 1961 (Otawa, 1963), 39; Ray Marshall and Beth Paulen, "Employment and Eannings of Women: Historical Perspectives," in Working Women: Past, Present, Future, cd. Karen Shallecross Koziara e! al. (Washington: Bureau of National Affairs 1987), 8 . 
worked briefly in offices or department stores before marrying. For others these occupations served as stepping stones to business careers. $95^{\circ}$ As Lynn Gordon notes, "The new emphasis on business careers reflected Vassar women's desire for a greater role in the 'man's world' and their growing emphasis on individual achievement." 96 A 1915 survey of some 17,000 alumnae from elite eastern colleges found that almost 70 percent had been "gainfully employed," and a survey of some 6,600 women who had been students at land-grant universities between 1889 and 1922 reported that " 55 percent were working in the late 1920 s, and that almost 82 percent had worked at some time." 97

Reflecting the country's wider economic base, its more rapid urban growth, and its earlier industrialization than Canada's, the scale of such opportunities would appear to have been greater in the United States. ${ }^{98}$ Dalhousie women at the turn of the century had similar ambitions to these of their American counterparts, but evidently fewer opportunities to realize them. Consequently, many left the Maritimes for employment, further education, or marriage in the United States. ${ }^{90}$ Economic opportunities for graduates were better in central Canada. Of those who could be traced, Queen's University graduates between 1895 and 1900 (male and female combined) were employed mainly in education, health, and the clergy. A small but growing proportion were working in commercial occupations. A significant minority (18 percent of men and 11 percent of women) moved for occupational or other reasons to the United States.

A study of American college alumni who graduated between 1928 and 1935 indicated the continuation of earlier employment trends in the United States. Eight percent of the women graduates reported owning their own or part of a business. Fully 52 percent reported beginning their working lives in the clerical trades, a figure which declined to 40 percent after eight years, as women left the workforce, advanced in their careers, or moved into other fields. 101 Another study

95. Gordon, Gender and Higher Education in the Progressive Era, 160-62, 197.

96. Ibid., 160 .

97. Sicheman, "College and Careers," 138.

98. According to Graham Lowe, "Al a very general level, ...the rise of modern capitalist economies rested on the twin pillars of thriving manufacturing and services sectors. Centralized bureaucracies became the standard form of work organizations. The blue-collar proletariat, prominent actors in the nineteenth-century industrialization process, eventually were overshadowed by expanding white-collar occupations. Foremost anong these were office clerks and managers. These developments surfaced in Canada somewhat after their appearance in the United States, Britain on Gemany." Women in the Administrative Revolution, 25.

99. Judith Fingard, "College, Career, and Community: Dalhousie Co-eds, 1881-1921," in Youth, University and Canadian Society, ed. Axelrod and Reid, 45.

100. Chad Gafficld, Lynn Marks, and Susan Laskin, "Student Populations and Graduate Careers: Queen's University, 1895-1900," in Youth, University, and Canadian Society, ed. Axelrod and Reid, 17-19.

101. Walter J. Greenleaf, The Economic Status of College Alumni (Washington: Office 
conducted in 1940 by Lawrence Babcock, on the careers of university graduates across the country, showed that 17.3 percent of working women were engaged in business, and 82.7 in the professions. ${ }^{102}$ While there were no comparable national surveys in Canada, a study of women graduates at Dalhousie University (the largest university in the Maritimes) found that the majority who graduated between 1926 and 1940 evidenty did not obtain employment. ${ }^{103}$

Professional women with university training were also in greater demand in the United States than in Canada. As Table 9 shows, in 1930, American women constituted a slightly larger portion of the professional workforce in teaching, the law, and the clergy, and a significantly larger component of librarians and university faculty. Whereas only 11 percent of Canadian professorial positions in colleges and university were occupied by women, in the United States women held 32 percent of academic positions. The larger and expanding higher education system in the United States created its own labour market for university graduates, including women. Female colleges, in particular, provided outlets for such employment that simply did not exist in Canada.

For the professions as a whole, including males, the similarities between Canada and the United States are striking. In 1930-31,6.1 percent of the Canadian and 6 percent of the American workforces were categorized as professional. ${ }^{104}$ As Table 10 shows, the proportion of the population in each of the major professional groups in both countries was similar as well. Lawyers constituted 0.3 percent of the total American workforce and 0.2 per cent of the Canadian. The largest professional group, teachers, was proportionately the same size in the two countries. This would imply, perhaps surprisingly, given the comparative size of the American economy and the far larger size of its university population, that the proportionate demand for university-trained professionals was virtually identical in Canada and the United States in 1930. The proportion of the professionally trained middle class grew at roughly the same rate in the two countries in the period up to 1930 .

of Education, United States Department of the Interior, 1939), 60-61. The study was based on 46,000 replies drawn from 130 American colleges.

102. F. Lawrence Babcock, The U.S. College Graduate (New York: MacMillan, 1941), 23.

103. Axelrod, Making a Middle Class, 156. Some 72 percent of women graduates of 1921 reported on their occupations, a figure which dropped to 41 percent in 1926 and 33 per cent in 1931. The response and employment rates of men were far higher for the same years. The figures must be areated cautionsly. They are based on the reported occupations of those who could be traced through alumni records. It is likely that at least a portion of those unable to be traced were able to find employment following graluation.

104. Dominion Bureau of Statistics, Occupational Trends in Canada, 1931 to 1961,40; Janet M. Hooks, Women's Occupations through Seven Decades (Washington: United States Department of Labor, Women's Bureau Bulletin, no. 218, 1951), 206. 
Table 9: Occupations of Women Workers

\begin{tabular}{|c|c|c|c|c|}
\hline & \multicolumn{2}{|c|}{ U.S. 1930} & \multicolumn{2}{|c|}{ Canada 1931} \\
\hline & $\mathrm{N}$ & $\begin{array}{c}\% \text { of } \\
\text { occupation }\end{array}$ & $\mathrm{N}$ & $\begin{array}{c}\% \text { of } \\
\text { occupation }\end{array}$ \\
\hline Professors, college pres. & 19,930 & 31.9 & 223 & 10.8 \\
\hline Teachers & 853,967 & 81.7 & 64,950 & 77.4 \\
\hline Physicians and surgeons & 6.825 & 4.4 & 259 & 8.1 \\
\hline Librarians $^{\mathrm{a}}$ & 26,785 & 91.3 & 1,399 & 31.2 \\
\hline Lawyers ${ }^{b}$ & 3,385 & 2.1 & 54 & 0.7 \\
\hline Dentists & 1,338 & 1.9 & 24 & 1.8 \\
\hline Clergymen & 3,276 & 2.2 & 32 & 0.8 \\
\hline
\end{tabular}

Notes: "Census category in Canada is "librarians, authors, journalists."

"Census category in Canada is "lawyers and notaries," and in the U.S., "lawyers and judges."

Sources: Janet M. Hooks, Women's Occupations through Seven Decades (Washington: United States Department of Labor, Women's Bureau Bulletin no. 218, 1951), Appendix Tables IIA, 208, and IIB, 224; Dominion Bureau of Statistics, Occupational Trends in Canada, 1891 to 1931 (Ottawa, 1939), 20-28, Table 9; Dominion Bureau of Statistics, Occupational Trends in Canada, 1931 to 1961 (Ottawa, 1963), 40-48, Tables 4, 5 .

However, differences arise with respect to labour market opportunities for educated employees in the private sector. The expansion of the professional, industrial, and service sectors was considerable in both countries at the turn of the century, but by virtue of its later industrialization and administrative modernization, Canadian business development lagged in comparison to that in the U.S. ${ }^{105}$ By 1930, the total white-collar sector in the United States constituted 28.8 percent of the labour force, compared to 24.4 percent in Canada, a situation which created a potentially larger labour market for university graduates south of the border. The more rapid expansion of the American economy was indicated also by the fact that the agricultural sector employed 28.8 percent of the Canadian labour force in 1930 , compared to 21.4 percent of the American. ${ }^{106}$ In the

105. Lowe, Women in the Administrative Revolution, 25-35; see also Sanford M. Jacoby, Employing Bureaucracy: Managers, Unions, and the Transformation of Work in American Industry, 1900-1945 (New York: Columbia University Press, 1985), 26. 106. H. Dewey Anderson and Percy E. Davidson, Occupational Trends in the United 
Table 10: Professions in United States and Canada

\begin{tabular}{|l|r|r|r|r|}
\hline & \multicolumn{2}{|c|}{ U.S 1930 } & \multicolumn{2}{c|}{ Canada 1931 } \\
\cline { 2 - 5 } & \multicolumn{1}{|c|}{$\mathrm{N}$} & $\begin{array}{c}\text { \% of } \\
\text { workforce }\end{array}$ & \multicolumn{1}{c|}{$\mathrm{N}$} & \multicolumn{1}{c|}{$\begin{array}{c}\% \text { of } \\
\text { workforce }\end{array}$} \\
\hline Professors, college pres. & 62,524 & 0.120 & 3,200 & 0.08 \\
\hline Teachers & $1,044,016$ & 2.150 & 83,928 & 2.10 \\
\hline Architects & 23,100 & 0.040 & 1,298 & 0.03 \\
\hline Engineers & 229,132 & 0.470 & 15,850 & 0.40 \\
\hline Clergymen & 145,871 & 0.300 & 13,126 & 0.30 \\
\hline Dentists & 70,344 & 0.099 & 4,039 & 0.10 \\
\hline Lawyers, judges & 160,605 & 0.300 & 8,058 & 0.20 \\
\hline Physicians, surgeons & 153,803 & 0.300 & 10,020 & 0.25 \\
\hline Nurses & 294,189 & 0.600 & 31,898 & 0.80 \\
\hline All occupations & $48,594,592$ & & $3,927,230$ & \\
\hline
\end{tabular}

Note: ${ }^{2}$ Includes graduate nurses and nurses-in-training.

Sources: Janet M. Hooks, Women's Occupations through Seven Decades (Washington: United States Department of Labor, Women's Bureau Bulletin no. 218, 1951), Appendix Tables IIA, 208, and IIB, 224; Dominion Bureau of Statistics, Occupational Trends in Canada, 1891 10 1931 (Ottawa, 1939), 20-28, Table 9; Dominion Bureau of Statistics, Occupational Trends in Canada, 1931 101961 (Ottawa, 1963), 40-48, Tables 4, 5.

category of administrative and managerial personnel, there were greater prospects for employment in the United States than in Canada. In 1930 "administrators and managers" in business enterprises constituted 11.9 percent of the American workforce, or 5,810,760 individuals, whereas in Canada those employed as "proprietors and managers" constituted 5.6 percent or 235,309 members of the labour force. 107

The American statistics refer to occupation by "economic function," and the Canadian to occupational category. Babcock's 1940 (U.S.) study, referred to

States (Stanford: Stanford University Press, 1940), 16-17; DBS, Occupational Trends in Canada, 1931-1961, 37.

107. Anderson and Davidson, Occupational Trends in the United States, 16-17,31; DBS, Occupational Trends in Canada, 1931-1961,37. These figures must be interpreted cautiously. 
earlier, found that 62.8 percent of male university graduates were in the professions and 37.2 percent were employed in business occupations. ${ }^{108}$

Finally, it should be noted that American institutions in the 1920s significantly expanded the business training component of higher education. Between 1919 and 1924, 117 new programmes in business were introduced in American colleges and universities. ${ }^{09}$ As David $O$. Levine notes,

In supporting the colleges, businessmen expected them to become both training facilities and socializing agents for the burgeoning white-collar middle class....Managerial capitalism had created new industries as well as new levels of managemen. Knowledge replaced instinct as the practitioners' chief asset, if only because most business decisions were made by middle-level managers far removed from the "big picture" and from ownership. The growing sectors of the economy-finance capitalism and mass marketing-appear to require a different kind of businessman from the traditional industrial entrepreneur. ${ }^{110}$

In Canada, business education also expanded in the 1920s and 1930s-notably at the University of Western Ontario, which attempted 10 emulate the successful Harvard School of Business programme- but was evidently embraced, both by the academic and corporate communities, with less enthusiasm than in the United States. While some professors criticized the overly utilitarian thrust of business education, many employers expressed scepticism about the virtues of hiring universily graduates. Corporate employees who worked their way up from the ground floor were frequently perceived as more reliable and less demanding than the university-educated. ${ }^{11}$

Thus, while circumstantial in part, the available evidence suggests that from the late nineteenth century to 1930 , the range of suitable employment opportunities for the university-trained, both men and women, was greater in the United States than in Canada, particularly in the burgeoning private sector. A similar proportion of the workforce in both countries was classified as "professional" in 1930, but university-trained Americans with general degrees found wider em.

108. Babcock, The U.S. College Graduate, 22.

109. David O. Levine, The American College and the Culture of Aspiration (Ithaca: Comell Universily Press, 1986), 59.

110. Ibid., 46,54 .

111. Harris, A History of higher Education in Canada, 382-84; Axelrod, Making a Middle Class, 60-61. For a discussion of the debate surrounding the introduction of a commerce programme at Quecn's University in the 1920s, see Barry Ferguson, Remaking Liberalism: The Intellectual Legacy of Adam Short, O.D. Skelton, W.C. Clark, and W.A. Maclntosh, 1890-1925 (Montreal: McGill-Queen's University Press, 1993), 35-37. 
ployment possibilities in the private sector than was the case in Canada. The higher participation rate in American higher education was, in all likelihood, linked to the students' understanding of these labour market realities.

Able to build on a larger foundation of religious colleges, fuelled further by a wealthier business class, and economically situated to provide more employment possibilities for those with advanced training, higher education in the United States from the late nineteenth century to 1930 drew a higher proportion of its population to colleges and universities than was the case in Canada.

\section{Conclusion}

This historical study of higher education in North America has attempled to enhance our understanding of comparative university development. Inspired by a recent historiography which emphasizes the importance of nineteenth-century religion in the lives of Canadians and Americans, the article concludes that religious commitment, particularly of the evangelical variety, helps explain emerging differences in the growth of higher education in the two countries. Home to a proportionately larger evangelical movement seeking recognition and respectability, the United States wimessed the more rapid growth of higher educational institutions than did Canada. On the strength of a larger, more diverse, and more pecunious private sector, Americans were able to sustain the pace of expansion and student participation during the period of great industrial growth in the early twentieth century. The extension of Canadian higher education was also impressive, but the religious composition of the population in the nineteenth century, and the nature of economic development in the early twentieth, were sufficiently different that a proportionately smaller university sector was both produced and maintained. Statistical ambiguities require caution in conducting this type of comparative work. Nevertheless, attention to the interaction of evangelicalism and political economy, of religion and capitalism, appears to offer fresh historical insights into university development on the North American continent, and perhaps elsewhere. 